\title{
INNOVATIVE APPROACH FOR TOURISM ENTERPRISE IN ALBANIA
}

\author{
AlKIDA HASAJ, ${ }^{1}$ DRITA KRUJA ${ }^{2}$ \\ 1 University of Shkodra "Luigj Gurakuqi", ALBANIA \\ e-mail: alkidahasaj@yahoo.com \\ ${ }^{2}$ European University of Tirana, ALBANIA \\ e-mail: drita.kruja@uet.edu.al \\ \begin{tabular}{l|l} 
RECEIVED & 1 July 2016
\end{tabular} \\ \begin{tabular}{l|l} 
ACCEPTED & 1 November 2016
\end{tabular} \\ JEL \\ CLASSIFICATION \\ 130, L83 \\ KEYWORDS \\ tourism industry, challenge, innovation, competitiveness \\ ABSTRACT \\ The purpose of this study is to examine the current challenges and barriers to the Albania tourism enterprises \\ (such as; travel agencies, hotels and bar/restaurant) and attempts to reveal innovative approaches to cope with \\ these recent challenges and barriers. Innovation is at the heart of any successful company so it is very worthy \\ to discuss on the role that innovation plays in providing competitiveness. \\ The data were collected from some tourism enterprises that operate in Albania, like travel agencies, hotels and \\ bar/restaurant using a self completed questionnaire. The data gathered illustrate that the innovation in these \\ enterprises is driven basically by the owner-manager ambition to improve the existing facilities and services to \\ satisfy customers and develop a successful and reputable business. The research results can contributes to \\ travel agencies, hotels and bar/ restaurants management both academically and practically.
}

\section{Introduction}

Like other countries, Albania has promoted tourism as a major source of national income. However, this industry has experienced lots of difficulties and challenges during these years (Kruja, Lufi, Kruja, 2012). In the last 20 years the tourism industry has also faced the change of consumer demands, consumer demography, increased competition and unstable global geopolitics, etc. To deal with these current challenges and barriers, Albania tourism 
enterprises reveal innovative approaches as a solution. But still now there is a lack of studies about innovative approach on tourism enterprises in Albania. Over the past couple of years, the term "innovation" has increasingly been used to describe the behavior of tourism enterprises, destinations, and the tourism sector (Hjalager, 2001, p. 1). Innovation is at the heart of any successful company. Innovation is a mean of enhancing competitiveness and business performance of tourism enterprises.

The objectives of this research are:

- To identify the actual conditions and challenges of Albania tourism enterprises.

- To clarify the word innovation and to explain how does it cope with this challenge?

- To identify the barriers to innovation.

- To investigate the impact of innovative practices on performance and other outcomes of tourism enterprises in Albania.

The research questions are:

- What are the indicators of innovation?

- How are innovative ideas generated?

- What are the outcomes of innovation for the tourism enterprises in Albania?

- What are the barriers holding back innovation?

\section{Albania Tourism Industry and Tourism Enterprises}

Albania has unique ecological features that provide significant but under-utilized tourism potential, including coastal areas, mountainous terrains, rivers, parks, and protected areas. These natural features have the potential to attract tourists seeking ecological and cultural experiences. The tourism industry in Albania is currently focused on coastal areas. And in the recent years, an increasing number of foreign tourists are visiting Albania. This country has become a regional tourist destination after shaking its prolonged communist-era isolation, during which it fell into obscurity (Kruja, Hasaj, 2010, p. 1).

Tourism has been recognized as one of the driving forces of Albania's economy - providing jobs and income to thousands of families (Kruja, Gjyrezi, 2011). There is special interest in tourism development in the small regions. The contribution of tourism as a driver for economic development and growth at the regional and national scales has been widely acknowledged. However, less attention has been given to the role of tourism in facilitating and enabling regional knowledge transfer and innovation (Weidenfeld, Hall, 2014).

The direct contribution of Travel \& Tourism to GDP was ALL82.3 bn (5.9\% of total GDP) in 2014, and is forecast to fall by $2.1 \%$ in 2015 . This primarily reflects the economic activity generated by industries such as hotels, travel agents, airlines and other passenger transportation services (excluding commuter services). But it also includes, for example, the activities of the restaurant and leisure industries directly supported by tourists. Travel \& Tourism generated 50,500 jobs directly in 2014 (5.3\% of total employment) and this is forecast to remain the same in 2015 at 50,500 (5.1\% of total employment (WTTC, 2015).

\section{Innovation Process and Definition}

Innovation is a broad concept that has been defined using many approaches. It is a process by which firms add value through successful exploitation of a new idea for the benefit of a part or whole business, industry or the 
nation (Feeny, Rogers, 2003). A common definition describes innovation as involving the creation or application of new ideas (McCosh et al., 1998; Feeny, Rogers, 2003).

Table 1. The indicators of innovative capacity

\begin{tabular}{|c|c|}
\hline A record of significant growth, and having growth strategies in place & $\begin{array}{l}\text { Covin, Slevin, } 1991 \\
\text { Baldwin, Johnson, } 1995 \\
\text { Chandler, Keller, Lyon, } 2000 \\
\text { Mahemba, De Bruijn, } 2003\end{array}$ \\
\hline $\begin{array}{l}\text { Competent management as shown through skills, knowledge of industry, past experience } \\
\text { and the application of experience. Further, an effective awareness of contemporary issues } \\
\text { in the industry obtained through active environmental scanning }\end{array}$ & $\begin{array}{l}\text { Baldwin, Johnson, } 1995 \\
\text { Davis, Moe, } 1997 \\
\text { McAdam, Armstrong, Kelly, } 1998 \\
\text { Mahemba, De Bruijn, } 2003\end{array}$ \\
\hline $\begin{array}{l}\text { The existence and maintenance of external relationships by the manager and the knowledge } \\
\text { of the importance of these relationships }\end{array}$ & $\begin{array}{l}\text { Rothwell, } 1992 \\
\text { Cooper, } 1995 \\
\text { Hine, Ryan, } 1999 \\
\text { Breen, Bergin-Seers, Jago, Carlsen, } 2003 \\
\text { Mahemba, De Bruijn, } 2003\end{array}$ \\
\hline The successful management of information within the business & $\begin{array}{l}\text { Cebon, Newton, Noble, } 1999 \\
\text { Hine, Ryan, } 1999 \\
\text { Feeny, Rogers, } 2003 \\
\text { Mahemba, De Bruijn, } 2003\end{array}$ \\
\hline $\begin{array}{l}\text { The provision of unique products and services and the ability of the manager to recognize } \\
\text { the importance of product differentiation as a source of competitive advantage }\end{array}$ & $\begin{array}{l}\text { Cooper, } 1986 \\
\text { Baldwin, Johnson, } 1995\end{array}$ \\
\hline The recognition of the value of employees as an essential factor in business success & $\begin{array}{l}\text { McAdam, Armstrong, Kelly, } 1998 \\
\text { Hine, Ryan, } 1999 \\
\text { Baldwin, Gellately, } 2003\end{array}$ \\
\hline $\begin{array}{l}\text { The acknowledgment of customer relations as an important factor in business success; responsive } \\
\text { consideration and action on suggestions from customers }\end{array}$ & $\begin{array}{l}\text { Cooper, } 1986 \\
\text { Jones, Tilley, } 2003\end{array}$ \\
\hline $\begin{array}{l}\text { Market knowledge and the existence of marketing plans; awareness of the various media available } \\
\text { for advertising and appropriate use according to market segment }\end{array}$ & $\begin{array}{l}\text { Cooper, } 1986 \\
\text { Cooper, } 1995 \\
\text { Breen, Bergin-Seers, Jago, } 2003\end{array}$ \\
\hline A systematic new product development process & $\begin{array}{l}\text { Cooper, } 1995 \\
\text { Hine, Ryan, } 1999 \\
\text { Feeny, Rogers, } 2003\end{array}$ \\
\hline $\begin{array}{l}\text { An awareness of barriers to innovation that the owner/operator sees as relevant to their business } \\
\text { (having had or going to have to overcome) and the capacity to minimize political, operational } \\
\text { and cultural barriers to change }\end{array}$ & $\begin{array}{l}\text { Baldwin, Johnson, } 1995 \\
\text { Cebon, Newton, Noble, } 1999 \\
\text { Radnor and Robinson, } 2000 \\
\text { Baldwin, Gellatly, } 2003 \\
\text { Bessant, } 2003 \\
\text { Feeny, Rogers, } 2003\end{array}$ \\
\hline
\end{tabular}

Source: Breen, Bergin-Seers, Roberts, Frew, Carlsen (2006), p. 7.

The Austrian economist Joseph Schumpeter is a pioneer when we talk about innovation management. Without doubt Schumpeter develops important ideas with regard to innovation: innovation as source of economic change (Schumpeter, 1928; 1942, pp. 81-86; 1947), technological innovation as source of business cycle (Schumpeter, 1912; 1939). Early at 1934 Schumpeter identified five different types of innovation (as cited in Lewis, 2007, p. 36):

1. The introduction of a new product or a qualitative change in an existing product.

2. Process innovation new to an industry.

3. The opening of a new market. 
4. The development of new sources of supply for raw materials or other inputs.

5. Changes in industrial organization.

Economist and management consultant Peter Drucker once said, "An established company which, in an age demanding innovation, is not capable of innovation, is doomed to decline and extinction". Innovation has become a buzzword, regularly cited to convey any improvement made, regardless of the extent of newness (Brooker, Joppe, 2013). Today, many companies are taking steps to strengthen their ability to innovate - innovating to renovate the innovation process itself. In short, such companies are developing a reliable operating system for innovation, a key indicator of corporate sustainability (Smith, 2005).

Innovation may seem to be the preservation of big business. But it is an approach that can be used by all companies, especially start-ups and small businesses. After all, when a business comprises just the owner-operator or a handful of partners or employees, it lacks diversity of mind. Yet, diversity feeds creativity and innovation (Baumgartner, 2011).

It is widely held that innovation is a process that involves the actual vision to create new ideas or improve on existing resources and the knowledge and skills to implement them (Kuratko, Hodgetts, 2001; McCosh et al., 1998).

The following 10 indicators of innovative capacity are used as the basis to analyze the data collected during this study. The importance of these dimensions is then evaluated. Innovation is conceptualized not as a single event but as a process that produces ideas and transforms these to useful benefits. These benefits could be measured in terms of improved performance such as an increase in growth rate, market share or profitability.

\section{Methodology}

This study has used the primary and secondary data. The secondary data were achieved through an extensive literature review on innovation, what drives and motivates innovative behavior, the indicators of innovation and outcomes of innovative practices. Internal and external influences on the innovation process were also researched.

The primary data was collected through an online survey, which was distributed to some tourism enterprise in Albania. Data were collected from these enterprises using a self completed questionnaire, which included also Likert-scale questions. It was built in Qualtrics and distributed online.

Using questionnaire as research instrument enables the collection and analysis of quantitative data using descriptive statistics. The quantitative research method is a research on social and human problems, based on testing a theory of comprised of variables, measured with numbers and analyzed with statistical procedures, in such a way to gauge whether the theory forecast can be generalized (Creswell, 1994, p. 1). These data collected through questionnaire construction can be used to suggest possible reasons for certain connections between variables and to create models of these relationships (Saunders et al., 2011, p. 144). Khandwalla (1977) states, that there is no research method that can be considered the best. The survey of these tourism enterprises in Albania was conducted in two weeks, from 12 to 25 , September 2015. The questionnaire was pre-tested by 5 managers of tourism enterprises in the area.

The population for this study is all travel agencies, hotels, bar-restaurants that operate in Albania. For the selection of the sample has been used the databases available on Tax Office in Tirana, of all tourism entities like travel agencies, hotels and bar/restaurants that operate in Albania. A list of these businesses was created and then the sample from 200 enterprises was using the Simple random sampling. Simple random sampling is best used 
when you have an accurate and easily accessible sampling frame that lists the entire population, preferably stored on a computer (Saunders, Lewis, Thornhill, 2011).

From these questionnaires delivered only 173 were replied. The response rate is about $86.5 \%$. Given the response rate and representation of many tourism enterprises in different areas, the sample was considered to be the representative.

Based on Albania law travel agencies, hotels and bar/restaurants are defined as:

- "Travel agency" means any physical or legal person who, directly or as an intermediary, undertakes to offer tourists and other people, as individuals or organized group, any travel service, including accommodation in host structure for tourists, consulting and provision of air travel, the land of the sea, of organized excursions, as well as a range of other ancillary services related to the tourism industry. Travel agency develops its activity based on contracts for the sale of mediation services provided by the suppliers of travel services and/or consultancy contract with the customer (KRSH, 2015).

- The "hotels" are considered building with no less than 6 rooms, where accommodation and services like food, drinks etc. provided by a qualified staff, at a set of price (KRSH, 2015).

- "Restaurant" is an enterprise that supplies food available to the public, where the main purpose is the sale of food for consumption outside or inside a bar (environment), and offer a table or bar service in accordance with established standards (KRSH, 2007).

\section{Research Findings}

From the business surveyed, $85.7 \%$ were travel agencies, $15.8 \%$ hotels and the rest $8.4 \%$ were bar and restaurants. The majority of them $71.4 \%$ are positioned in urban areas, while $28.6 \%$ in rural area. $57.14 \%$ of these tourism enterprises have about 4 to 10 years operating in this industry. The average yearly growth in turnover (over the past 2 years) was $1-10 \%$ for $57.14 \%$ of these enterprises, $11-20 \%$ for $28.57 \%$ of them, and for only $14.29 \%$ were $0 \%$ of growth. The growth is a significant predictor of innovation.

About the use of information technology, the most common applications used in their businesses were emails (95.7\%), basic PC applications (71.42\%), Booking Reservation System (86\%) and websites (85.7\%). Zero percent of these enterprises use a customer management system/database.

The management styles is expressed with a continuum of a seven-point scale from (traditional) placing emphasis on marketing of tried products and services, with a rating of 1 to dynamic or placing emphasis on research, technological leadership and innovation, with a rating of 7 . A small percentage of respondents expressed a tendency towards a traditional style (average 3.36).

Tahle 2. Ratings of innovative tendency (\%)

\begin{tabular}{|c|c|c|c|c|c|c|}
\hline $\begin{array}{c}\text { Traditional: } \\
\text { placing emphasis } \\
\text { on marketing of tried } \\
\text { products and services } \\
1\end{array}$ & 2 & 3 & 4 & 5 & 6 & $\begin{array}{c}\text { Dynamic: } \\
\text { emphasis on research, } \\
\text { technological leadership } \\
\text { and innovation } \\
7\end{array}$ \\
\hline 8.8 & 17.5 & 30.7 & 22.1 & 14.3 & 1.7 & 4.9 \\
\hline
\end{tabular}

Source: survey results. 
Another question considers the offer of new products and services in these last two years. This question was a seven point scale, from no offering new products and services (1) to many new offering (7). Low innovators were defined as including scores between 1 and 2.5; medium included scores between 3 and 5 ; and high included scores between 5.5 and 7 .

The scores were very concentrated in the middle with the highest percentage 32.1 and with (overall average 3.97). This result show that this enterprises are medium innovative, they create new products and service but not many.

Table 3. Ratings of new products and services introduced (\%)

\begin{tabular}{|c|c|c|c|c|c|c|}
\hline $\begin{array}{c}\text { No new products } \\
\text { or services } \\
\text { have been introduced } \\
1\end{array}$ & 2 & 3 & 4 & 5 & 6 & $\begin{array}{c}\text { Many new products } \\
\text { and services have } \\
\text { been introduced } \\
7\end{array}$ \\
\hline 6.8 & 8.5 & 21.7 & 32.1 & 18.1 & 2.1 & 10.7 \\
\hline
\end{tabular}

Source: survey results.

Important to consider too, is that some of these tourism enterprises are managed by the owner and the process of developing new products and services was developed by themselves, or taking in consideration the support of some other employees. So, the innovation in these enterprises is driven basically by the owner-manager's ambition to improve the existing facilities and services to satisfy customers and develop a successful and reputable business. The manager plays the central and crucial role in ensuring that innovations occur. Keeping ahead of competition is a continuing concern of innovative mangers.

For an innovative business is extremely important to get informed about its business environment. For this reason was asked these enterprises the information gathering techniques used to know about their business environment. The scale ranging from never (1) to frequently (7) was used. From the reply the most commonly used practices were routine gathering of information from customers (5.1), routine gathering of information from suppliers (4.9) and industry publication (4.7). Specific market research studies (2.1) were used least frequently.

These results show that tourism enterprises that operates in Albania didn't do research to know about business environment. Maybe this happens because the research is considered from them expensive, they do not consider it important, or they do not know how to do it.

To know the barriers of the innovation was asked a question about the factors that restrict the ability of these businesses to introduce new products and services. The scale ranging from not at all restrictive (1) to extremely restrictive (7) was used. In rating the restrictiveness of various aspects affecting their ability to introduce new products and services the most restrictive aspect was considered the availability of quality employees (5.71), and local government regulations (4.7).

\section{Conclusions}

From the research that was done in innovative approach for the tourism enterprise in Albania, we arrived to some conclusions as follow:

- The tourism enterprises in Albania are made up of mostly small and medium operators. 
- The innovation in these enterprises is driven basically by the owner-manager's ambition to improve the existing facilities and services to satisfy customers and develop a successful and reputable business.

- Costumer's suggestions are the primary source of innovation ideas.

- The analyses also determined that more innovativeness is associated with businesses that are growing, have more employees, have ease of access to finance for developing their businesses, and are aware of competition.

- The adaptation of the innovation in these enterprises will create more satisfied and loyal customers. As a result, these enterprises which innovate, achieve business sustainability by most tourism enterprises in Albania.

- At the centre of innovative enterprises, one finds attentive managers that initiate and implement required innovations. These managers are sometimes the owner of this business.

- From this research, it was also found that the attitudes of those considered as the "high innovator" differ, compared to those "less innovative". The high innovators network with external people to develop new products and services. They demonstrate active networking and environmental scanning behaviors.

The research results can contributes to travel agencies, hotels and bar/ restaurants management both academically and practically.

Some suggestion to these tourism enterprises that operate in Albania will be:

- To be more costumers oriented.

- To become member of more associations, the affiliation is a significant predictor of innovativeness.

- To have more dynamic management style because it is a significant predictor of innovativeness.

- To proactively seek innovative ideas. To do this through keeping close to customers and getting their feedback and suggestions, and through networking with external stakeholders.

- To consider continuously the suggestions that comes from employees, who are also recognized as a source of innovative ideas.

- To become more proactive in gathering information about the business environment.

\section{References}

Baumgartner, J. (2011). Open innovation for small companies, May, 2011. Available at: http://www.innovationtools.com/Articles/ EnterpriseDetails.asp?a $=643$.

Breen, J., Bergin-Seers, S., Roberts, L., Frew, E. \& Carlsen, J. (2006). Innovation and change management for small and medium tourism enterprises in the tourist park sector. Cooperative Research Centre for Sustainable Tourism, Gold Coast.

Brooker, E. \& Joppe, M. (2013). Developing a tourism innovation typology: Leveraging liminal insights. Journal of Travel Research. DOI: 0047287513497839.

Cebon, P., Newton, P. \& Noble, P. (1999). Innovation in firms: towards a framework for indicator development. Melbourne Business School, Working Paper.

Creswell, J.W. (2013). Research design: Qualitative, quantitative, and mixed methods approaches. Sage publications.

Feeny, S. \& Rogers, M. (2003). Innovation and performance: Benchmarking Australian firms. Australian Economic Review, 36 (3), 253-264.

Hjalager, A.M. (2002). Repairing innovation defectiveness in tourism. Tourism management, 23 (5), 465-474.

Khandwalla, P.N. (1977). The design of organizations. Houghton Mifflin Harcourt P.

KRSH (Kuvendi i Republikes se Shqiperise) (2007). Ligji Nr. 9734, date 14.5.2007 "Për Turizmin Dokumenta, Formulare, Klasifikime dhe Rregullore". 
KRSH (Kuvendi i Republikes se Shqiperise) (2015). Ligji Nr. 93/2015 “Për Turizmin”, Neni 4.

Kruja, D. \& Gjyrezi, A. (2011). The special interest tourism development and the small regions. Turizam, 15 (2), 77-89.

Kruja, D. \& Hasaj, A. (2010). Comparisons of stakeholders' perception towards the sustainable tourism development and its impacts in Shkodra Region (Albania). Turizam, 14 (1), 1-14.

Kruja, D., Lufi, M. \& Kruja, I. (2012). The Role of Tourism in Developing Countries. The case of Albania. European Scientific Journal, 8 (19).

Lewis, D.E. (2007). An investigation into the relationship between product innovation, trust, and diversity. ProQuest.

McCosh, A., Smart, A., Barrar, P. \& Lloyd, A. (1998). Proven methods for innovation management: an executive wish list. Creativity and Innovation Management, 7 (4), 175-192.

Saunders, M.N. (2011). Research methods for business students, 5/e. Pearson Education India. Fifth edition.

Schumpeter, J. (1928). The instability of capitalism. The Economic Journal, 38 (151), 361-386.

Schumpeter, J.A. (1934). The theory of economic development: An inquiry into profits, capital, credit, interest, and the business cycle (Vol. 55). Transaction publishers.

Schumpeter, J.A. (1939). Business cycles: a theoretical, historical, and statistical analysis of the capitalist process. McGraw-Hill.

Schumpeter, J.A. (1947). The creative response in economic history. The Journal of Economic History, 7 (02), 149-159.

Smith, H. (2005). What Innovation Is? CTO. European Office of Technology and Innovation.

Weidenfeld, A. \& Hall, C.M. (2014). Tourism in the development of regional and sectoral innovation systems. The Wiley Blackwell companion to tourism, $578-588$.

WTTC (2015). Albania, Travel and Tourism, Economic Impact.

Cite this anticle aS: Hasaj, A., Kruja, D. (2016). Innovative Approach for Tourism Enterprise in Albania. European Journal of Service Management, 20 (4), 17-24. DOI: 10.18276/ejsm.2016.20-02. 